\title{
The modified Medical Research Council scale for the assessment of dyspnea in daily living in obesity: a pilot study
}

\author{
Claire Launois $^{{ }^{*}}$, Coralie Barbe ${ }^{2}$, Eric Bertin ${ }^{3}$, Julie Nardi ${ }^{1}$, Jeanne-Marie Perotin ${ }^{1}$, Sandra Dury ${ }^{1}$,
} François Lebargy ${ }^{1}$ and Gaëtan Deslee ${ }^{1}$

\begin{abstract}
Background: Dyspnea is very frequent in obese subjects. However, its assessment is complex in clinical practice. The modified Medical Research Council scale (mMRC scale) is largely used in the assessment of dyspnea in chronic respiratory diseases, but has not been validated in obesity. The objectives of this study were to evaluate the use of the mMRC scale in the assessment of dyspnea in obese subjects and to analyze its relationships with the 6-minute walk test (6MWT), lung function and biological parameters.

Methods: Forty-five obese subjects (17 M/28 F, BMl: $\left.43 \pm 9 \mathrm{~kg} / \mathrm{m}^{2}\right)$ were included in this pilot study. Dyspnea in daily living was evaluated by the mMRC scale and exertional dyspnea was evaluated by the Borg scale after 6MWT. Pulmonary function tests included spirometry, plethysmography, diffusing capacity of carbon monoxide and arterial blood gases. Fasting blood glucose, total cholesterol, triglyceride, N-terminal pro brain natriuretic peptide, C-reactive protein and hemoglobin levels were analyzed.

Results: Eighty-four percent of patients had a $m M R C \geq 1$ and $40 \%$ a $m M R C \geq 2$. Compared to subjects with no dyspnea ( $m M R C=0)$, a $m M R C \geq 1$ was associated with a higher BMI ( $44 \pm 9$ vs $36 \pm 5 \mathrm{~kg} / \mathrm{m}^{2}, p=0.01$ ), and a lower expiratory reserve volume (ERV) (50 \pm 31 vs $91 \pm 32 \%, p=0.004)$, forced expiratory volume in one second $\left(F E V_{1}\right)$ ( $86 \pm 17$ vs $101 \pm 16 \%, p=0.04)$ and distance covered in $6 \mathrm{MWT}$ (401 \pm 107 vs $524 \pm 72 \mathrm{~m}, \mathrm{p}=0.007)$. A mMRC $\geq 2$ was associated with a higher Borg score after the 6MWT $(4.7 \pm 2.5$ vs $6.5 \pm 1.5, \mathrm{p}<0.05)$.

Conclusion: This study confirms that dyspnea is very frequent in obese subjects. The differences between the "dyspneic" and the "non dyspneic" groups assessed by the mMRC scale for BMI, ERV, FEV 1 and distance covered in $6 \mathrm{MWT}$ suggests that the mMRC scale might be an useful and easy-to-use tool to assess dyspnea in daily living in obese subjects.
\end{abstract}

Keywords: Dyspnea, Obesity, Modified Medical Research Council scale, Six-minute walk test, Lung function

\section{Background}

Obesity, defined as a Body Mass Index (BMI) greater than or equal to $30 \mathrm{~kg} / \mathrm{m}^{2}$, is a significant public health concern. According to the World Health Organization, worldwide obesity has more than doubled since 1980 and in 2008 there were about 1.5 billion overweight adults $\left(25 \leq \mathrm{BMI}<30 \mathrm{~kg} / \mathrm{m}^{2}\right)$. Of these, over 200 million men and nearly 300 million women were obese [1].

\footnotetext{
* Correspondence: launois.claire@gmail.com

${ }^{1}$ Service des Maladies Respiratoires, INSERM UMRS 903, Hôpital Maison Blanche, CHU de Reims, 45 rue Cognacq Jay 51092, Reims Cedex, France Full list of author information is available at the end of the article
}

Dyspnea is very frequent in obese subjects. In a large epidemiological study, $80 \%$ of obese patients reported dyspnea after climbing two flights of stairs [2]. In a series of patients with morbid obesity, Collet et al. found that patients with a BMI $>49 \mathrm{~kg} / \mathrm{m}^{2}$ had more severe dyspnea assessed with BDI (Baseline Dyspnea Index) than obese patients with a BMI $\leq 49 \mathrm{~kg} / \mathrm{m}^{2}$ [3]. The most frequent pulmonary function abnormalities associated with obesity $[4,5]$ are a decrease in expiratory reserve volume (ERV) [6-8], functional residual capacity (FRC) [6-8], and an increase in oxygen consumption [9]. Although the mechanisms of dyspnea in obesity remain

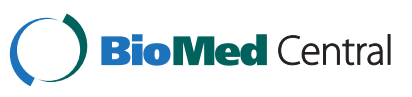


unclear, it is moderately correlated with lung function [3,10-16]. Of note, type 2 diabetes [17], insulin resistance [18] and metabolic syndrome [19] have been shown to be associated with reduced lung function in obesity. It must be pointed out that dyspnea is a complex subjective sensation which is difficult to assess in clinical practice. However, there is no specific scale to assess dyspnea in daily living in obesity. The modified Medical Research Council (mMRC) scale is the most commonly used validated scale to assess dyspnea in daily living in chronic respiratory diseases [20-22] but has never been assessed in the context of obesity without a coexisting pulmonary disease.

The objectives of this pilot study were to evaluate the use of the mMRC scale in the assessment of dyspnea in obese subjects and to analyze its relationships with the 6-minute walk distance (6MWD), lung function and biological parameters.

\section{Methods \\ Patients}

Adult obese patients from the Department of Nutrition of the University Hospital of Reims (France) were consecutively referred for a systematic respiratory evaluation without specific reason and considered for inclusion in this study. Inclusion criteria were a BMI $\geq 30 \mathrm{~kg} / \mathrm{m}^{2}$ and an age $>18$ year-old. Exclusion criteria were a known coexisting pulmonary or neuromuscular disease or an inability to perform a 6MWT or pulmonary function testing. The study was approved by the Institutional Review Board (IRB) of the University Hospital of Reims, and patient consent was waived.

\section{Methods}

\section{Clinical characteristics and mMRC scale}

Demographic data (age, sex), BMI, comorbidities, treatments and smoking status were systematically recorded. Dyspnea in daily living was evaluated by the mMRC scale which consists in five statements that describe almost the entire range of dyspnea from none (Grade 0) to almost complete incapacity (Grade 4) (Table 1).

\section{Six-minute walk test}

The 6MWT was performed using the methodology specified by the American Thoracic Society (ATS-2002) [23]. The patients were instructed that the objective was to walk as far as possible during 6 minutes. The $6 \mathrm{MWT}$ was performed in a flat, long, covered corridor which was 30 meters long, meter-by-meter marked. Heart rate, oxygen saturation and modified Borg scale assessing subjectively the degree of dyspnea graded from 0 to 10 , were collected at the beginning and at the end of the $6 \mathrm{MWT}$. When the test was finished, the distance covered was calculated.

\begin{tabular}{|c|c|}
\hline Grade & Description of Breathlessness \\
\hline Grade 0 & I only get breathless with strenuous exercise \\
\hline Grade 1 & $\begin{array}{l}\text { I get short of breath when hurrying on level } \\
\text { ground or walking up a slight hill }\end{array}$ \\
\hline Grade 2 & $\begin{array}{l}\text { On level ground, I walk slower than people of the } \\
\text { same age because of breathlessness, or I have to stop } \\
\text { for breath when walking at my own pace on the level }\end{array}$ \\
\hline Grade 3 & $\begin{array}{l}\text { I stop for breath after walking about } 100 \text { yards or } \\
\text { after a few minutes on level ground }\end{array}$ \\
\hline Grade 4 & $\begin{array}{l}\text { I am too breathless to leave the house or } \\
\text { I am breathless when dressing }\end{array}$ \\
\hline
\end{tabular}

\section{Pulmonary function tests}

Pulmonary function tests (PFTs) included forced expiratory volume in one second $\left(\mathrm{FEV}_{1}\right)$, vital capacity (VC), forced vital capacity (FCV), $\mathrm{FEV}_{1} / \mathrm{VC}$, functional residual capacity (FRC), expiratory reserve volume (ERV), residual volume (RV), total lung capacity (TLC) and carbon monoxide diffusing capacity of the lung (DLCO) (BodyBox 5500 Medisoft Sorinnes, Belgium). Results were expressed as the percentage of predicted values [24]. Arterial blood gases were measured in the morning in a sitting position.

\section{Biological parameters}

After 12 hours of fasting, blood glucose, glycated hemoglobin (HbAIc), total cholesterol, triglyceride, Nterminal pro brain natriuretic peptide (NT-pro BNP), Creactive protein (CRP) and hemoglobin levels were measured.

\section{Statistical analysis}

Quantitative variables are described as mean \pm standard deviation (SD) and qualitative variables as number and percentage. Patients were separated in two groups according to their dyspnea: $\mathrm{mMRC}=0$ (no dyspnea in daily living) and $m M R C \geq 1$ (dyspnea in daily living, ie at least short of breath when hurrying on level ground or walking up a slight hill).

Factors associated with mMRC scale were studied using Wilcoxon, Chi-square or Fisher exact tests. Factors associated with Borg scale were studied using Wilcoxon tests or Pearson's correlation coefficients. A p value $<$ 0.05 was considered statistically significant. All analysis were performed using SAS version 9.0 (SAS Inc, Cary, NC, USA).

\section{Results and discussion}

Demographic characteristics

Fifty four consecutive patients with a BMI $\geq 30 \mathrm{~kg} / \mathrm{m}^{2}$ were considered for inclusion. Of these, 9 patients were 
excluded because of an inability to perform the 6MWT related to an osteoarticular disorder $(n=2)$ or because of a diagnosed respiratory disease $(n=7 ; 5$ asthma, 1 hypersensitivity pneumonia and 1 right pleural effusion).

Results of 45 patients were considered in the final analysis. Demographic characteristics of the patients are presented in Table 2. Mean BMI was $43 \pm 9 \mathrm{~kg} / \mathrm{m}^{2}$, with $55 \%$ of the patients presenting an extreme obesity $\left(\mathrm{BMI} \geq 40 \mathrm{~kg} / \mathrm{m}^{2}\right.$, grade 3$)$. Regarding smoking status, $56 \%$ of patients were never smokers and $11 \%$ were current smokers. The main comorbidities were hypertension (53\%), dyslipidemia (40\%) and diabetes (36\%). Severe obstructive sleep apnea syndrome was present in 16 patients (43\%).

\section{Dyspnea assessment by the mMRC scale and 6MWT}

Results of dyspnea assessment are presented in Table 3. Dyspnea symptom assessed by the mMRC scale was very frequent in obese subjects with $84 \%(n=38)$ of patients with a mMRC scale $\geq 1$ and $40 \%(n=18)$ of patients with a mMRC scale $\geq 2(29 \% m M R C=2,9 \% m M R C=3$ and $2 \% \mathrm{mMRC}=4$ ).

The mean distance covered in 6MWT was $420 \pm 112 \mathrm{~m}$. Sixteen percent of patients had a decrease > $4 \%$ of $\mathrm{SpO} 2$ during the $6 \mathrm{MWT}$ and one patient had a $\mathrm{SpO} 2<90 \%$ at the end of the $6 \mathrm{MWT}$ (Table 4). The dyspnea sensation at rest was very slight $($ Borg $=1 \pm 1.5)$ but severe after exertion (Borg $=5.4 \pm 2.4)$. Fifty-three percent of patients exhibited a Borg scale $\geq 5$ after the $6 \mathrm{MWT}$ which is considered as severe exertional

Table 2 Clinical characteristics of the $\mathbf{4 5}$ adult obese patients

\begin{tabular}{lc}
\hline Age & Total $(\mathbf{n}=\mathbf{4 5})$ \\
Sex $(\mathrm{M} / \mathrm{F})$ & $51 \pm 11$ \\
BMI $\left(\mathrm{kg} / \mathrm{m}^{2}\right)$ & $17 / 28$ \\
$30 \leq \mathrm{BMl}<35\left(\mathrm{~kg} / \mathrm{m}^{2}\right)($ grade 1$)$ & $43 \pm 9$ \\
$35 \leq \mathrm{BMl}<40\left(\mathrm{~kg} / \mathrm{m}^{2}\right)$ (grade 2$)$ & $7(16 \%)$ \\
$\geq 40\left(\mathrm{~kg} / \mathrm{m}^{2}\right)(\mathrm{grade} 3)$ & $13(29 \%)$ \\
Smoking history & $25(55 \%)$ \\
Current & \\
Previous & $5(11 \%)$ \\
Never & $15(33 \%)$ \\
Pack-years & $25(56 \%)$ \\
Comorbidities & $10 \pm 17$ \\
Hypertension & \\
Diabetes & $24(53 \%)$ \\
Dyslipidemia & $16(36 \%)$ \\
Apnea/hypopnea index scores $(\mathrm{n} / \mathrm{h})(\mathrm{n}=35)$ & $18(40 \%)$ \\
\hline
\end{tabular}

Data are expressed as mean \pm SD or number (\%).
Table 3 Dyspnea assessment of the $\mathbf{4 5}$ adult obese patients

\begin{tabular}{lc}
\hline & Total $(\mathbf{n}=\mathbf{4 5})$ \\
\hline mMRC scale $(0-4)$ & $1.4 \pm 0,9$ \\
mMRC scale $\geq 1$ & $38(84 \%)$ \\
mMRC scale $\geq 2$ & $18(40 \%)$ \\
Borg scale at rest (1-10) & $1 \pm 1,5$ \\
Borg scale at rest $\geq 1$ & $25(56 \%)$ \\
Borg scale after $6 \mathrm{MWT}(1-10)$ & $5.4 \pm 2.4$ \\
Borg scale after $6 \mathrm{MWT} \geq 5$ & $24(53 \%)$
\end{tabular}

Data are expressed as mean \pm SD or number (\%).

mMRC: modified Medical Research Council, 6MWT: six-minute walk test.

dyspnea. No complication occurred during the 6MWT. Subjects with a mMRC score $\geq 2$ had a higher Borg score after the 6MWT than subjects with a mMRC score $<2$ $(6.5 \pm 1.5$ vs $4.7 \pm 2.5, \mathrm{p}<0.05)$.

Table 4 Functional characteristics of the $\mathbf{4 5}$ adult obese patients

patients

\begin{tabular}{lc}
\hline & Total $(\mathbf{n}=\mathbf{4 5})$ \\
\hline Spirometry $(\mathbf{n}=\mathbf{4 5})$ & \\
$\mathrm{FEV}_{1}, \%$ pred & $88 \pm 18$ \\
$\mathrm{VC}_{1} \%$ pred & $92 \pm 20$ \\
$\mathrm{FEV}_{1}<80 \%$ & $13(29 \%)$ \\
$\mathrm{FEV}_{1} / \mathrm{NC}$ & $0.77 \pm 0.10$ \\
$\mathrm{FEV}_{1} / \mathrm{VC}<0.7$ & $5(11 \%)$
\end{tabular}

Plethysmography $(\mathbf{n}=\mathbf{3 8})$

$\begin{array}{lc}\text { FRC,\% pred } & 94 \pm 23 \\ \text { ERV,\% pred } & 56 \pm 34 \\ \text { TLC,\% pred } & 98 \pm 17 \\ \text { TLC }<80 \% & 5(13 \%) \\ \text { DLCO,\% pred } & 83 \pm 18 \\ \text { DLCO }<70 \% & 10(26 \%)\end{array}$

Arterial blood gases $(n=43)$

$\begin{array}{lc}\mathrm{pH} & 7.42 \pm 0,03 \\ \mathrm{PaO} 2(\mathrm{mmHg}) & 90 \pm 16 \\ \mathrm{PaO} 2 \leq 70 \mathrm{mmHg} & 0(0 \%) \\ \mathrm{PaCO} 2(\mathrm{mmHg}) & 39 \pm 4 \\ \mathrm{PaCO} 2>45 \mathrm{mmHg} & 0(0 \%)\end{array}$

Walking test $(n=45)$

6-minute walk distance (m) $\quad 420 \pm 112$

SpO2 at rest (\%) $\quad 97 \pm 2$

SpO2 after 6MWT (\%) $\quad 95 \pm 2$

Decrease $>4 \%$ of $\mathrm{SpO} 2 \quad 7(16 \%)$

SpO2 after $6 \mathrm{MWT}<90 \% \quad 1(2 \%)$

Data are expressed as mean \pm SD or number (\%).

$\mathrm{FEV}_{1}$ : expiratory volume in one second, VC: vital capacity, FRC: functional residual capacity, ERV: expiratory reserve volume, TLC: total lung capacity, DLCO: carbon monoxide diffusing capacity of the lung, pred: predicted value, 6MWT: six-minute walk test. 


\section{Lung function tests}

Results of spirometry, plethysmography and arterial blood gases are shown in Table 4. Overall, the PFTs results remained in the normal range for most of the patients, except for ERV predicted values which were lower (ERV $=56$ $\pm 34 \%$ ). There were an obstructive ventilatory disorder defined by a $\mathrm{FEV}_{1} / \mathrm{VC}<0.7$ in 5 patients $(11 \%)$ with 5 patients $(13 \%)$ exhibiting a $\mathrm{mMRC} \geq 1$, a restrictive ventilatory disorder defined by a TLC $<80 \%$ in 5 patients $(13 \%)$ with 5 patients $(16 \%)$ exhibiting a $m M R C \geq 1$, and a decrease in alveolar diffusion defined by DLCO $<70 \%$ in 10 patients (26\%) with 9 patients $(28 \%)$ exhibiting a $m M R C \geq$ 1. Arterial blood gases at rest were in the normal range with no hypoxemia $<70 \mathrm{mmHg}$ and no significant hypercapnia $>45 \mathrm{mmHg}$.

\section{Biological parameters}

Fifteen percent $(n=7)$ of patients presented anemia. All patients had a hemoglobin level $\geq 11 \mathrm{~g} / \mathrm{dL}$. Mean NT proBNP was $117 \pm 285 \mathrm{pg} / \mathrm{mL}$. Four patients (10\%) had a proBNP $>300 \mathrm{pg} / \mathrm{mL}$.Forty-five percent of patients had a fasting glucose level $>7 \mathrm{mmol} / \mathrm{L}, 51 \%$ a Hbalc $>6 \%, 29 \%$ a triglyceride level $\geq 1.7 \mathrm{mmol} / \mathrm{L}, 35 \%$ a total cholesterol level > $5.2 \mathrm{mmol} / \mathrm{L}$ and $31 \%$ a CRP level $>10 \mathrm{mg} / \mathrm{L}$.

\section{Relationships between the mMRC scale and clinical characteristics, PFTs and biological parameters}

The comparisons between the mMRC scale and demographic, lung functional and biological parameters are shown in Table 5 . Subjects in the $\mathrm{mMRC} \geq 1$ group had a higher BMI $(\mathrm{p}=0.01)$ (Figure 1A), lower ERV $(\mathrm{p}<0.005)$ (Figure 1B), $\mathrm{FEV}_{1}(\mathrm{p}<0.05)$, covered distance in $6 \mathrm{MWT}(\mathrm{p}<0.01)$ (Figure $1 \mathrm{C})$ and Hb level $(\mathrm{p}<0.05)$ than subjects in the $\mathrm{mMRC}=0$ group. Of note, there was no association between the mMRC scale and age, sex, smoking history, arterial blood gases, metabolic parameters and the apnea/hypopnea index.

The relationships between the Borg scale after 6MWT and demographic, lung functional and biological parameters were also analysed. The Borg score after 6MWT was correlated with a higher BMI (correlation coefficient = $+0.44, \mathrm{p}<0.005$ ) and a lower $\mathrm{FEV}_{1}$ (correlation coefficient $=-0.33, \mathrm{p}<0.05$ ). No relationship was found between the Borg score after 6MWT and ERV or hemoglobin level. The Borg score after 6MWT was correlated with a higher fasting glucose (correlation coefficient $=+0.46, \mathrm{p}<0.005$ ) whereas this parameter was not associated with the mMRC scale (data not shown). We found no statistically different change in Borg scale ratings of dyspnea from rest to the end of the 6MWT between the two groups $(\mathrm{p}=0.39)$.

In this study, 45 consecutive obese subjects were specifically assessed for dyspnea in daily living using the mMRC scale. Our study confirms the high prevalence of
Table 5 Comparisons of patients with $\mathrm{mMRC}=\mathbf{0}$ and patients with $\mathrm{mMRC} \geq 1$ concerning clinical characteristics, lung function and biological parameters

$M R C=0(n=7) \quad M R C \geq 1(n=38)$

Demographic characteristics

$\begin{array}{lcc}\text { Age } & 50 \pm 10 & 51 \pm 11 \\ \text { Sex }(\mathrm{M} / \mathrm{F}) & 4 / 3 & 13 / 25 \\ \left.\text { BMI (kg/m }{ }^{\mathbf{2}}\right) & 36 \pm 5 & 44 \pm 9^{*} \\ \text { Smoking history } & & \\ \text { Pack-years } & 10 \pm 16 & 10 \pm 17 \\ \text { PFTs } & & \\ \text { FEV } 1 \% \text { pred } & 101 \pm 16 & 86 \pm 17^{*} \\ \text { VC,\% pred } & 103 \pm 15 & 90 \pm 20 \\ \text { FEV } 1 \text { NC } & 0.78 \pm 0.05 & 0.77 \pm 0.11 \\ \text { FRC,\% pred } & 100 \pm 16 & 91 \pm 25 \\ \text { ERV } \% \text { pred } & 91 \pm 32 & 50 \pm 31^{* *} \\ \text { TLC,\% pred } & 101 \pm 11 & 97 \pm 17 \\ \text { DLCO,\% pred } & 86 \pm 18 & 83 \pm 19\end{array}$

\section{Arterial blood gases}

$\begin{array}{lcc}\mathrm{PaO} 2(\mathrm{mmHg}) & 99 \pm 24 & 88 \pm 14 \\ \mathrm{PaCO} 2(\mathrm{mmHg}) & 39 \pm 4 & 39 \pm 4\end{array}$

6-minute walk test

6-minute walk distance $(\mathrm{m})$

$\begin{array}{cc}524 \pm 72 & 401 \pm 107^{* *} \\ 98 \pm 2 & 97 \pm 2 \\ 94 \pm 2 & 96 \pm 2 \\ 0.1 \pm 0.4 & 1.1 \pm 1.6 \\ 3.9 \pm 3 & 5.7 \pm 2.1\end{array}$

Biological parameters

$\begin{array}{lcc}\text { Hemoglobin }(\mathrm{g} / \mathrm{dL}) & 14.8 \pm 1,3 & 13.7 \pm 1,5^{*} \\ \text { NT pro-BNP }(\mathrm{pg} / \mathrm{mL}) & 97 \pm 199 & 121 \pm 301 \\ \text { CRP }(\mathrm{mg} / \mathrm{L}) & 5 \pm 4,9 & 9.1 \pm 7,4 \\ \text { Triglyceride }(\mathrm{mmol} / \mathrm{L}) & 1.9 \pm 0,9 & 1.5 \pm 0,8 \\ \text { Total cholesterol }(\mathrm{mmol} / \mathrm{L}) & 5.4 \pm 1 & 4.7 \pm 1 \\ \text { Fasting glucose }(\mathrm{mmol} / \mathrm{L}) & 5.3 \pm 0,8 & 7.8 \pm 3,3 \\ \text { Hba1c }(\%) & 5.7 \pm 0,6 & 6.8 \pm 1,6\end{array}$

Data are expressed as number (\%) or mean \pm SD; ${ }^{*} p$ value $<0.05,{ }^{* *} p$ value $<0.01$. $\mathrm{FEV}_{1}$ : expiratory volume in one second, pred: predicted value, VC: vital capacity, FRC: functional residual capacity, ERV: expiratory reserve volume, TLC: total lung capacity, DLCO: carbon monoxide diffusing capacity of the lung, NT pro-BNP: $\mathrm{N}$-terminal pro brain natriuretic peptide, CRP: serum $\mathrm{C}$ reactive protein, HbA1c: glycated hemoglobin.

Normal biological parameters values were based on the normal values for our laboratory: fasting glucose: 3.3 to $6.1 \mathrm{mmol} / \mathrm{L} ; \mathrm{HbA} 1 \mathrm{c}$ : 4 to $6 \%$; total cholesterol: 3 to $5.2 \mathrm{mmol} / \mathrm{L}$; triglycerides: 0.3 to $1.7 \mathrm{mmol} / \mathrm{L}$; NT-pro $\mathrm{BNP}<300 \mathrm{pg} / \mathrm{mL} ; \mathrm{CRP}<10 \mathrm{mg} / \mathrm{L}$. Anemia was defined as hemoglobin level $<13 \mathrm{~g} / \mathrm{dL}$ in men and $12 \mathrm{~g} / \mathrm{dL}$ in women.

dyspnea in daily living in obese subjects [2] with $84 \%$ of patients exhibiting a mMRC scale $\geq 1$ and $40 \%$ a mMRC scale $\geq 2$. Interestingly, the presence of dyspnea in daily living $(\mathrm{mMRC} \geq 1)$ was associated with a higher BMI and a lower ERV, $\mathrm{FEV}_{1}$, distance covered in 6MWT and 

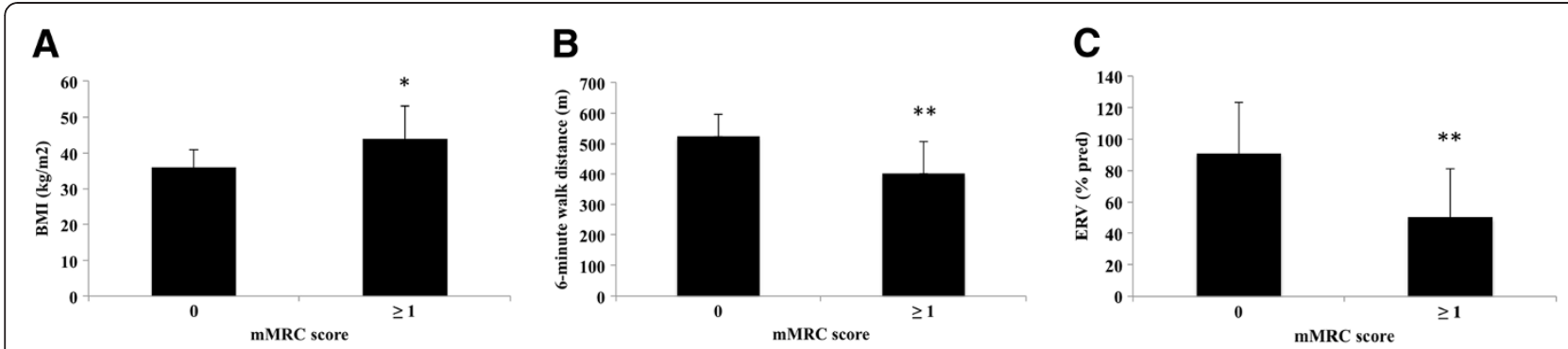

Figure 1 Differences in Body Mass Index (BMI) (A), Expiratory reserve volume (ERV) (B) and 6-minute walk distance (C) between non-dyspneic (modified Medical Research Council score $=0$ ) and dyspneic (mMRC score $\geq 1$ ) subjects. ${ }^{*} p<0.05$, ${ }^{* *} p<0.01$. A Wilcoxon test was used.

hemoglobin level. Furthermore, a mMRC score $\geq 2$ in obese subjects was associated with a higher Borg score after the 6MWT (data not shown).

The assessment of dyspnea in clinical practice is difficult. Regarding the mMRC scale, two versions of this scale have been used, one with 5 grades [20] as used in this study and an other with 6 grades [25] leading to some confusion. Other scales have been also used to assess dyspnea [26]. Collet at al. [3], Ofir et al. [11] and El-Gamal [27] et al provided some evidence to support the use of the BDI, Oxygen cost diaphragm (OCD) and Chronic Respiratory Disease Questionnaire (CRQ) to evaluate dyspnea in obesity. El-Gamal et al [27] demonstated the responsiveness of the CRQ in obesity as they did measurements before and after gastroplaty-induced weight loss within the same subjects. The Baseline Dyspnea Index (BDI) uses five grades (0 to 4 ) for 3 categories, functional impairment, magnitude of task and magnitude of effort with a total score from 0 to 12 [28]. The University of California San Diego Shortness of Breath Questionnaire comprises 24 items assessing dyspnea over the previous week [29]. It must be pointed out that these scores are much more time consuming than the mMRC scale and are difficult to apply in clinical practice.

To our knowledge, the mMRC scale has not been investigated in the assessment of dyspnea in daily living in obese subjects without a coexisting pulmonary disease. The mMRC scale is an unidimensional scale related to activities of daily living which is widely used and well correlated with quality of life in chronic respiratory diseases [20] such as chronic obstructive pulmonary disease (COPD) [21] or idiopathic pulmonary fibrosis [22]. The mMRC scale is easy-to-use and not time consuming, based on five statements describing almost the entire range of dyspnea in daily living. Our study provides evidence for the use of the mMRC scale in the assessment of dyspnea in daily living in obese subjects. Firstly, as expected, our results demonstrate an association between the mMRC scale and the BMI in the comparison between "dyspneic" and "non dyspneic" groups. Secondly, in our between-group comparisons, the mMRC scale was associated with pulmonary functional parameters (lower ERV, FEV 1 and distance walked in 6MWT) which might be involved in dyspnea in obesity. The reduction in ERV is the most frequent functional respiratory abnormality reported in obesity [6-8]. This decrease is correlated exponentially with BMI and is mainly due to the effect of the abdominal contents on diaphragm position [30]. While the $\mathrm{FEV}_{1}$ might be slightly reduced in patients with severe obesity, the $\mathrm{FEV}_{1} / \mathrm{VC}$ is preserved as seen in our study [31]. The determination of the walking distance and the Borg scale using the $6 \mathrm{MWT}$ is known to be a simple method to assess the limitations of exercise capacity in chronic respiratory diseases [23]. Two studies have shown a good reproducibility of this test $[32,33]$ but did not investigate the relationships between the 6MWD and dyspnea in daily living. Our study confirms the feasibility of the 6MWD in clinical practice in obesity and demonstrates an association between covered distance in 6MWT and the presence or the absence of dyspnea in daily living assessed by the mMRC scale. It must be pointed out that the 6MWT is not a standardized exercise stimulus. Exercise testing using cycloergometer or the shuttle walking test could be of interest to determine the relationships between the mMRC scale and a standardize exercise stimulus. In our between-group comparisons, $\mathrm{BMI}$ and $\mathrm{FEV}_{1}$ were associated with the mMRC scale and correlated with the Borg scale after 6MWT. Surprisingly, the ERV was associated with the mMRC scale but not with the Borg scale. Moreover, the fasting glucose was correlated with the Borg scale after 6MWT but not associated with the mMRC scale. Whether these differences are due to a differential involvement of these parameters in dyspnea in daily living and at exercise, or simply related to a low sample size remains to be evaluated.

As type 2 diabetes, insulin resistance, metabolic syndrome [17-19], anemia and cardiac insufficiency have been shown to be associated with lung function and/or 
dyspnea, we also investigated the relationships between dyspnea in daily living and biological parameters. A mMRC scale $\geq 1$ was associated with a lower hemoglobin level. However, all patients had a hemoglobin level $>11 \mathrm{~g} / \mathrm{dL}$ and the clinical significance of the association between dyspnea in daily living and a mildly lower hemoglobin level has to be interpreted cautiously and remains to be evaluated. Of note, we did not find any associations between the mMRC scale and triglyceride, total cholesterol, fasting glucose, HbA1C, CRP or NT pro-BNP.

The strength of this study includes the assessment of the relationships between the mMRC scale and multidimensional parameters including exertional dyspnea assessed by the Borg score after 6MWT, PFTs and biological parameters. The limitations of this pilot study are as follows. Firstly, the number of patients included is relatively low. This study was monocentric and did not include control groups of overweight and normal weight subjects. Due to the limited number of patients, our study did not allow the analysis sex differences in the perception of dyspnea. Secondly, we did not investigate the relationships between the mMRC scale and other dyspnea scales like the BDI which has been evaluated in obese subjects and demonstrated some correlations with lung function [3]. Thirdly, it would have been interesting to assess the relationships between the mMRC scale and cardio-vascular, neuromuscular and psycho-emotional parameters which might be involved in dyspnea. Assessing the relationships between health related quality of life and dyspnea would also be useful. Finally, fat distribution (eg Waist circumferences or waist/hip ratios) has not been specifically assessed in our study but might be assessed at contributing factor to dyspnea. Despite these limitations, this pilot study suggests that the mMRC scale might be of value in the assessment of dyspnea in obesity and might be used as a dyspnea scale in further larger multicentric studies. It remains to be seen whether it is sensitive to changes with intervention.

\section{Conclusions}

This pilot study investigated the potential use of the mMRC scale in obesity. The differences observed between the "dyspneic" and the "non dyspneic" groups as defined by the mMRC scale with respect to BMI, ERV, $\mathrm{FEV}_{1}$ and distance covered in 6MWT suggests that the mMRC scale might be an useful and easy-to-use tool to assess dyspnea in daily living in obese subjects.

\section{Abbreviations}

BMI: Body Mass Index; mMRC scale: Modified Medical Research Council scale; 6MWT: Six-minute walk test; PFTs: Pulmonary function tests; FEV ${ }_{1}$ : Expiratory volume in one second; VC: Vital capacity; FVC: Forced vital capacity;

FRC: Functional residual capacity; ERV: Expiratory reserve volume; RV: Residual volume; TLC: Total lung capacity; DLCO: Carbon monoxide diffusing capacity of the lung; HbA1c: Glycated hemoglobin; NT pro-BNP: N-terminal pro brain natriuretic peptide; CRP: Serum C reactive protein.

\section{Competing interests}

None of the authors of the present manuscript have a commercial or other association that might pose a conflict of interest.

\section{Authors' contributions}

$C L, C B, E B, J N, J M P, S D, F L$ and $G D$ conceived the study. $C L$ acquired data. $C B$ performed the statistical analysis. $C L$ and GD drafted the manuscript. All authors read and approved the manuscript prior to submission.

\section{Acknowledgements}

We thank the personnel of the Department of Nutrition and Pulmonary Medicine of the University Hospital of Reims for the selection and clinical/ functional assessment of the patients.

\section{Author details}

'Service des Maladies Respiratoires, INSERM UMRS 903, Hôpital Maison Blanche, CHU de Reims, 45 rue Cognacq Jay 51092, Reims Cedex, France. ${ }^{2}$ Unité d'Aide Méthodologique, Pôle Recherche et Innovations, Hôpital Robert Debré, $\mathrm{CHU}$ de Reims, Reims, France. ${ }^{3}$ Service

d'Endocrinologie-Diabétologie-Nutrition, Hôpital Robert Debré, CHU de Reims, Reims, France.

Received: 6 April 2012 Accepted: 22 September 2012

Published: 1 October 2012

\section{References}

1. WHO: Obesity and overweight. http://www.who.int/mediacentre/factsheets/ fs311/en/.

2. Sjöström L, Larsson B, Backman L, Bengtsson C, Bouchard C, Dahlgren S, Hallgren P, Jonsson E, Karlsson J, Lapidus L: Swedish obese subjects (SOS). Recruitment for an intervention study and a selected description of the obese state. Int J Obes Relat Metab Disord. 1992, 16:465-479.

3. Collet F, Mallart A, Bervar JF, Bautin N, Matran R, Pattou F, Romon M, Perez T: Physiologic correlates of dyspnea in patients with morbid obesity. Int $J$ Obes (Lond) 2007, 31:700-706.

4. Salome CM, King GG, Berend N: Physiology of obesity and effects on lung function. J Appl Physiol 2010, 108:206-211.

5. Gibson GJ: Obesity, respiratory function and breathlessness. Thorax 2000, 55(Suppl 1):S41-S44.

6. Ray CS, Sue DY, Bray G, Hansen JE, Wasserman K: Effects of obesity on respiratory function. Am Rev Respir Dis 1983, 128:501-506.

7. Jones RL, Nzekwu M-MU: The effects of body mass index on lung volumes. Chest 2006, 130:827-833.

8. Biring MS, Lewis MI, Liu JT, Mohsenifar Z: Pulmonary physiologic changes of morbid obesity. Am J Med Sci 1999, 318:293-297.

9. Babb TG, Ranasinghe KG, Comeau LA, Semon TL, Schwartz B: Dyspnea on exertion in obese women: association with an increased oxygen cost of breathing. Am J Respir Crit Care Med 2008, 178:116-123.

10. Sahebjami H: Dyspnea in obese healthy men. Chest 1998, 114:1373-1377.

11. Ofir $D$, Laveneziana $P$, Webb KA, O'Donnell DE: Ventilatory and perceptual responses to cycle exercise in obese women. J Appl Physiol 2007, 102:2217-2226.

12. Romagnoli I, Laveneziana P, Clini EM, Palange P, Valli G, de Blasio F, Gigliotti $F$, Scano G: Role of hyperinflation vs. deflation on dyspnoea in severely to extremely obese subjects. Acta Physiol (Oxf) 2008, 193:393-402.

13. Jensen $D$, Webb KA, Wolfe LA, O'Donnell DE: Effects of human pregnancy and advancing gestation on respiratory discomfort during exercise. Respir Physiol Neurobiol 2007, 156:85-93.

14. Scano G, Stendardi L, Bruni Gl: The respiratory muscles in eucapnic obesity: their role in dyspnea. Respir Med 2009, 103:1276-1285.

15. Ora J, Laveneziana P, Ofir D, Deesomchok A, Webb KA, O'Donnell DE: Combined effects of obesity and chronic obstructive pulmonary disease on dyspnea and exercise tolerance. Am J Respir Crit Care Med 2009, 180:964-971. 
16. Sava F, Laviolette L, Bernard S, Breton M-J, Bourbeau J, Maltais F: The impact of obesity on walking and cycling performance and response to pulmonary rehabilitation in COPD. BMC Pulm Med 2010, 10:55.

17. Lecube A, Sampol G, Muñoz X, Hernández C, Mesa J, Simó R: Type 2 diabetes impairs pulmonary function in morbidly obese women: a casecontrol study. Diabetologia 2010, 53:1210-1216.

18. Lecube A, Sampol G, Muñoz X, Lloberes P, Hernández C, Simó R: Insulin resistance is related to impaired lung function in morbidly obese women: a case-control study. Diabetes Metab Res Rev 2010, 26:639-645.

19. Leone N, Courbon D, Thomas F, Bean K, Jégo B, Leynaert B, Guize L, Zureik M: Lung function impairment and metabolic syndrome: the critical role of abdominal obesity. Am J Respir Crit Care Med 2009, 179:509-516.

20. Mahler DA, Wells CK: Evaluation of clinical methods for rating dyspnea. Chest 1988, 93:580-586.

21. Hajiro T, Nishimura K, Tsukino M, Ikeda A, Koyama H, Izumi T: Analysis of Clinical Methods Used to Evaluate Dyspnea in Patients with Chronic Obstructive Pulmonary Disease. Am J Respir Crit Care Med 1998, 158:1185-1189.

22. Nishiyama O, Taniguchi H, Kondoh Y, Kimura T, Kato K, Kataoka K, Ogawa $\mathrm{T}$, Watanabe $\mathrm{F}$, Arizono S: A simple assessment of dyspnoea as a prognostic indicator in idiopathic pulmonary fibrosis. Eur Respir J 2010, 36:1067-1072.

23. ATS statement: guidelines for the six-minute walk test. Am J Respir Crit Care Med 2002, 166:111-117.

24. Standardized lung function testing. Official statement of the European Respiratory Society. Eur Respir J Supp/ 1993, 16:1-100.

25. Eltayara L, Becklake MR, Volta CA, Milic-Emili J: Relationship between chronic dyspnea and expiratory flow limitation in patients with chronic obstructive pulmonary disease. Am J Respir Crit Care Med 1996, 154:1726-1734.

26. Gerlach Y, Williams MT, Coates AM: Weighing up the evidence-a systematic review of measures used for the sensation of breathlessness in obesity. Int J Obes 2012.

27. El-Gamal H, Khayat A, Shikora S, Unterborn JN: Relationship of dyspnea to respiratory drive and pulmonary function tests in obese patients before and after weight loss. Chest 2005, 128:3870-3874.

28. Mahler DA, Weinberg DH, Wells CK, Feinstein AR: The measurement of dyspnea. Contents, interobserver agreement, and physiologic correlates of two new clinical indexes. Chest 1984, 85:751-758.

29. Eakin EG, Resnikoff PM, Prewitt LM, Ries AL, Kaplan RM: Validation of a new dyspnea measure: the UCSD Shortness of Breath Questionnaire. University of California, San Diego. Chest 1998, 113:619-624.

30. Parameswaran K, Todd DC, Soth M: Altered respiratory physiology in obesity. Can Respir J 2006, 13:203-210.

31. Sin DD, Jones RL, Man SFP: Obesity is a risk factor for dyspnea but not for airflow obstruction. Arch Intern Med 2002, 162:1477-1481.

32. Beriault K, Carpentier AC, Gagnon C, Ménard J, Baillargeon J-P, Ardilouze J-L, Langlois M-F: Reproducibility of the 6-minute walk test in obese adults. Int J Sports Med 2009, 30:725-727.

33. Larsson UE, Reynisdottir S: The six-minute walk test in outpatients with obesity: reproducibility and known group validity. Physiother Res Int 2008, 13:84-93.

doi:10.1186/1471-2466-12-61

Cite this article as: Launois et al.: The modified Medical Research

Council scale for the assessment of dyspnea in daily living in obesity: a pilot study. BMC Pulmonary Medicine 2012 12:61

\section{Submit your next manuscript to BioMed Central and take full advantage of:}

- Convenient online submission

- Thorough peer review

- No space constraints or color figure charges

- Immediate publication on acceptance

- Inclusion in PubMed, CAS, Scopus and Google Scholar

- Research which is freely available for redistribution 